\title{
X: 133319777-133360216
}

National Cancer Institute

\section{Source}

National Cancer Institute. X: 133319777-133360216. NCI Thesaurus. Code C42489.

Physical location of HPRT1_Gene 